\title{
POSTKOMODIFIKASI PORTAL BERITA DI KOMPAS.COM PADA PEMBERITAAN VAKSIN COVID-19
}

\author{
Bayquni $^{*}$, Prasetya Yoga Santoso ${ }^{2}$ \\ ${ }^{1,2}$ Universitas Prof. Dr. Moestopo (Beragama), Jakarta, Indonesia \\ "bayquni_bayu@yahoo.com
}

\begin{abstract}
Abtract
The Indonesian government has issued a government policy to overcome the transmission of Covid 19 in the country. Massive media reports, one of which is Kompas.com. The coverage of the Covid-19 vaccine on Kompas.com for the period August - September 2020 is the object of this research. The purpose of this study is to analyze, and reveal how the political discourse in the news of the Covid 19 Vaccine and how the post-commodification of information occurs through the news of the Covid 19 vaccine on Kompas.com. This research is an interpretive qualitative research with a critical paradigm with Norman Fairclough's Critical Discourse Analysis. Discourse analysis in this theory is carried out at three levels, namely text, discursive practice, and sociocultural practice. The results of the study show that the political discourse that has developed in the news of the Covid 19 vaccine on Kompas.com is the practice of media commodification. Political discourse in reporting the Covid-19 vaccine is represented as an identity battle between related parties, especially in government circles. The news on the Covid 19 vaccine, narrated by Kompas.com, is very political to gain recognition, support, and representation of media ideology by turning news into a millennial industry, ammunition for political competition and political partisan identity within the government.
\end{abstract}

Keywords: post commodification; cyber media; norman fairclough's critical discours; kompas.com

\begin{abstract}
Abstrak
Pemerintah Indonesia telah mengeluarkan kebijakan pemerintah dalam mengatasi penularan Covid 19 di tanah air. Media secara masif memberitakan, salah satunya Kompas.com. Liputan vaksin Covid-19 di Kompas.com periode Agustus - September 2020 menjadi objek penelitian ini. Tujuan penelitian ini untuk menganalisis, dan mengungkap bagaimana wacana politik dalam pemberitaan Vaksin Covid 19 dan bagaimana pasca komodifikasi informasi terjadi melalui pemberitaan vaksin Covid 19 di Kompas.com. Penelitian ini merupakan penelitian kualitatif interpretatif dengan paradigma kritis dengan Analisis Wacana Kritis Norman Fairclough. Analisis wacana dalam teori ini dilakukan pada tiga tataran, yaitu teks, praktik diskursif, dan praktik sosiokultural. Hasil penelitian menunjukkan bahwa wacana politik yang berkembang dalam pemberitaan vaksin Covid 19 di Kompas.com adalah pada praktik komodifikasi media. Wacana politik dalam pemberitaan vaksin Covid 19 direpresentasikan sebagai pertarungan identitas antar pihak terkait, terutama di lingkungan pemerintahan. Pemberitaan Vaksin Covid 19 dinarasikan Kompas.com sangat politis untuk mendapatkan pengakuan, dukungan, dan representasi ideologi media dengan menjadikan berita sebagai industri milenial, amunisi persaingan politik dan identitas partisan politik di internal pemerintahan.
\end{abstract}

Kata Kunci: post komodifikasi; media siber; wacana kritis norman fairclough's; kompas.com

\section{PENDAHULUAN}

Kehadiran Internet berdampak mematikan bagi sebagian besar industri media cetak. Secara substansi, Internet telah mengubah pola konsumsi informasi di masyarakat. Orang lebih banyak membaca informasi dari Internet (yang gratis dan uptodate). Sebagai akibatnya, basis pembaca dan tiras media cetak semakin turun. Konsekuensinya, jumlah 
dan nilai pengiklan pun turun drastis sementara biaya operasional cenderung stagnan bahkan meningkat. Korban sudah berjatuhan. Tahun 2014, Kelompok Kompas Gramedia (KKG) menutup 9 media cetaknya. Berdasarkan data The Nielsen Company, sepanjang tahun 2015 ada 16 surat kabar dan 38 majalah gulung tikar (Ridwan, 2017).

Dalam situasi normal, proses komunikasi yang bisa dikatakan sebagai pertukaran informasi kini telah jauh melampaui konsep dasar komunikasi itu sendiri. Banyaknya media online atau situs penyedia informasi dan penyebaran informasi yang masif membanjiri masyarakat telah menjadikan informasi kehilangan nilai guna dan kedalaman maknanya. Kecepatan telah menjadi paradigma baru dalam komunikasi postmodern, yang mengarahkan manusia pada ruang komunikasi dan informasi yang bebas dalam permainan bahasa dan tanda.

Dimana menurut Yasraf (Amir et al., 2001) wacana komunikasi lebih merayakan kegairahan dan ekstasi komunikasi itu sendiri. Dalam komunikasi kita saat ini apa saja diinformasikan. Informasi terus saja diproduksi hingga melampaui kegunaannya, dipertukarkan dan justru menjadi komoditas, dapat menjadi informasi sekalipun tidak informatif, dangkal, dan remeh serta mengabaikan logika, nilai guna, dan tujuan.

Dalam rangka memutus penularan Covid-19 pemerintah Indonesia akan melakukan vaksinasi kepada penduduk Indonesia. Hal ini sebagai salah satu solusi dalam memutus penularan Covid-19 khususnya bagi kalangan masyarakat yang memiliki mobilitas tinggi. Rencana vaksinasi ini mendapat perhatian media setelah Presiden menyatakan, pemerintah telah menyiapkan 290 juta dosis vaksin Covid-19 hingga akhir 2021. Hal itu disampaikan Jokowi saat membuka rapat terbatas tentang penanganan Covid-19 di
Istana Merdeka. Kompas.com (2020, Agustus 24).

Pemerintah menyebutkan bahwa rencana vaksinasi di Indonesia akan dilakukan dalam dua periode. Hal tersebut sudah dikonsutasikan kepada Indonesian Technical Advisory Group on Immunization (ITAGI) yang bertugas memberikan nasehat/advice kepada Menteri Kesehatan. Periode pertama akan dimulai pada Januari sampai dengan April 2021.

Program ini mendapat perhatian dari berbagai media karena dianggap sebagai sebuah terobosan penting sebagai salah satu cara menghadapi pandemi Covid-19. Program pemerintah terkait vaksinasi Covid-19. Media selalu memiliki pandangan tersendiri terhadap suatu peristiwa, dimana hal tersebut bersumber pada bagaimana suatu berita tersebut diproduksi, kedudukan wartawan dan media bersangkutan dalam keseluruhan proses produksi berita.

Media bukanlah saluran yang bebas atau seperti halnya mirror of reality yang menampilkan fakta suatu peristiwa apa adanya. Terhadap suatu peristiwa medialah yang mengkonstruk dan memberikan pemaknaan tersendiri dalam konteks pemahaman dan pengetahuannya sendiri (Karman, 2012).

Dalam konteks postmodern, fakta bukan segalanya dimana subjek terkadang juga ikut bermain. Fakta tak mesti hanya dilihat dari faktanya tapi juga kondisi subkjeknya. Penentu fakta dan makna ditentukan oleh subjeknya. Subyektifitas reflektif bahwa tak selalu obyek pengetahuan bersifat obyektif dan ini berkaitan dengan genealogi Foucault bahwa dibalik ilmu dibalik pengetahuan disana selalu ada kepentingan, kekuasaan bahkan keinginan untuk mendominasi Kepentingan sering menentukan isi pengetahuan, penggunaan pengetahuan dan perumusan. pengetahuan. Informasi bagaimanapun bentuknya saat ini telah sarat akan kepentingan dan terkendalikan 
menjadi sasaran komodifikasi. (Halim, 2013).

Kompas.com menjadi objek penelitian yang diambil peneliti karena dari riset awal media ini banyak memberitakan terkait vaksinasi yang akan dilakukan pemerintah. Sebagai media jaringan besar di tanah air yang masuk kelompok Kompas Gramedia, tentu pemberitaan yang disajikan tidak terlepas dari ideologi yang dianut media tersebut, posisi wartawan dan keseluruhan struktur sosial yang ada dalam masyarakat hingga pada akhirnya posisi tersebut kerap mempengaruhi arah pemberitaan suatu peristiwa. Dalam hal ini, paradigma mempertanyakan posisi wartawan dan media dalam keseluruhan struktur sosial yang ada di dalam masyarakat.

Kompas.com berusaha menyajikan berita-berita berkualitas. Akan tetapi sejatinya dalam konteks saat ini yang terjadi justru kualitas berita sudah tidak terlalu penting dibandingkan dengan narasi atas beritanya. Dalam wilayah postmodern, komodifikasi media bukan lagi berdasar pada produk tetapi padanarasi atas semua produk. Yang dikonsumsi masyarakat juga bukan lagi isiinformasi atas berita tetapi narasi atas semua produk media secara masal, narasiatas berita-berita yang diproduksi. (Kusuma, 2016)

Postkomodifikasi telah merubah identitas atau wajah media dari fungsi utamanya yakni informasi dan edukasi menjadi fungsi industri. Dimana dalam fungsi industri, edukasi dan informasi sudah tidak penting lagi dibandingkan dengan akumulasi keuntungan. (Halim, 2013)

Berkaitan dengan problem statement peneliti tersebut, peneliti akan memulai penyelidikan dari ranah teks untuk dianalisis dengan pisau bedah critical discourse analysis Norman Fairclough. Sebagaimana hal ini disinggung di awal mengenai kebebasan dalam permainan tanda dan bahasa dalam komunikasi, peneliti tertarik memilih teks berita pidato presiden dalam penanganan pandemi Covid 19 dengan berpijak pada konsep pemikiran postmodern yang dalam hal ini adalah postkomodifikasi media. (Halim, 2013)

\begin{tabular}{llr}
\multicolumn{2}{c}{ Bahwa } & \multicolumn{2}{c}{ postmodernisme } \\
bukanlah fase lanjutan & setelah \\
modernisme. & Demikian & pula
\end{tabular} postkomodifikasi bukan berarti lanjutan dari komodifikasi atau bahkan kontra dari komodifikasi. Dalam konteks cultural studies, Pembahasan dalam wilayah atau fase postmodern ini akan sangat bersifat dekonstruktif atau kritik atas sebuah realitas sebagai upaya mengurai relasi kekuasaan dibalik peristiwa komunikasi. Penegasan ini salah satunya berangkat dari pandangan Lyotard (1984) tentang postmodern atau pascamodern yang mengumumkan tak berlakunya lagi metanarasi. Katapost pada postmodernisme dalam pandangan Lyotard berarti sebuah prosedur analisis, anamnesis, anagogi, anamorfosis, yang menguraikan suatu kealpaan inisial, semua itu terbentang dihadapan rasionalitas yang diasosiasikan dengan narasi besar modern. Pandangan Lyotard (1984) tersebut juga memiliki kesamaan dengan Foucault bahwa pengetahuan tidak bersifat metafisis, transendental atau universal, melainkan spesifik menurut ruang dan waktu. Postmodern dalam pengertian ini bukan berarti kontra modern begitu juga postkomodifikasi bukan berarti kontra terhadap komodifikasi.

Sementara itu istilah komodifikasi (commodification) ditegaskan dalam kamus sosiologi sebagai the process in which goods and services are increasingly produced for the market. Compare subsistence economy". Sejalan dengan pengertian tersebut Vincent Mosco sebagaimana dikutip Subandy Ibrahim \& Bachruddin Ali Akhmad 
mendefinisikan bahwa komodifikasi merupakan sebuah proses mengubah barang dan jasa, termasuk komunikasi, yang dinilai karena kegunaannya, menjadi komoditas yang dinilai karena apa yang mereka berikan dipasar. Secara sederhana penulis memahami bahwa komodifikasi adalah proses transformasi barang dan jasa dari nilai gunanya menjadi komoditas yang mempunyai nilai tukar dan berfungsi mendatangkan keuntungan.

Kaitannya dengan penelitian ini informasi yang tersaji dalam sebuah teks berita mempunyai nilai guna untuk diketahui masyarakat. Tetapi informasi juga telah menjadi komoditas, diproduksi secara masal dan beralih menjadi nilai tukar yang bisa mendatangkan keuntungan bagi institusi media atau pihak lainnya. Dalam penelitian ini Postkomodifikasi diartikan sebagai kritik yang ditujukan terhadap praktik komodifikasi dan praktik wacana yang dilakukan oleh industri media, yakni Kompas.com

Kata siber dari asalnya yakni cyber banyak digunakan untuk menjelaskan realitas media baru yang ditandai dengan adanya internet dan polanya yang interactivity dengan khalayak. Dalam banyak literatur akademis penyebutan media siber mempunyai banyak istilah seperti media online, media virtual, media digital, media baru dan juga web.1.0 Penyebutan tersebut merujuk pada pemahaman yang serupa yakni perangkat media yang tidaksekedar pada makna teknnologinya saja tetapi juga pada banyak aspek kaitannya dengan aspek sosial, budaya, ekonomi, dan politik. Media siber dalam hal ini merepresentasikan medium komunikasi yang saling terintegrasi (konvergensi media) dalam ber bagai perspektif.

Merujuk pengertian media siber berdasarkan Pedoman Pemberitaan Media Siber yang disusun oleh Dewan Pers bersama organisasi pers dan pengelola media siber pada 3 Februari 2012 di
Jakarta sebagaimana dikutip oleh Rulli Nasrullah dalam Teori dan Riset Media Siber (cybermedia) menyebutkan media siber bahwa: Media siber adalah segala bentuk media yang menggunakan wahana internet dan melaksanakan kegiatan jurnalistik, serta memenuhi persyaratan Undang-Undang Pers dan Standar Perusahaan Pers yang ditetapkan Dewan Pers. Isi Buatan Pengguna (User Generated Content) adalah segala isi yang dibuat dan/atau dipublikasikan oleh pengguna media siber, antara lain artikel, gambar, komentar, suara, video dan berbagai bentuk unggahan yang melekat pada media siber, seperti blog, forum, komentar pembaca atau pemirsa, dan bentuk lain. (Nasrullah, 2015)

Dari pengertian media siber menurut Dewan Pers di atas dan subjek penelitian dalam penelitian ini yang merupakan portal berita berbasis internet yakni Kompas.Com yang melaksanakan kegiatan jurnalistik, dan telah tercatat di Dewan Pers maka dalam pengertian ini peneliti sepaham dengan pengertian media siber menurut Dewan Pers. Dan Kompas.com memenuhi kriteria sebagaimana yang dijelaskan untuk disebut sebagai media siber (Waluyo, 2017).

Pembacaan atas teks, permainan bahasadan tanda dalam penelitian ini akan menjadi gerbang dalam membongkar ideologi hingga sampai pada kritik atas praktik wacana dan praktik komodifikasi Kompas.com yang tersembunyi dibalik narasi berita pilpres 2019. Hal tersebut menjadi argumen bagi peneliti untuk mengatakan bahwa penelitian ini penting dan layak diperhitungkan sebagai upaya memunculkan kesadaran melek media bagi khalayak dan kesadaran untuk bertindak lebih profesional dan etis bagi industri media.

Dalam penelitian ini, peneliti akan menggunakan analisis wacana kritis model Norman Fairclough untuk mengkaji teks, produksi teks, dan praktik sosial budaya 
dalam kasus vaksinasiCovid-19yang diberitakan kompas.com untuk mencari realitas dari wacana sebuah teks berita yang disajikan. Pemilihan Kompas.com menjadi pertimbangan karena disesuaikan dengan pandangan analisis wacana yang bersifat kritis, selalu memandang teks, percakapan, sebagai praktik nilai-nilai dan pencerminan misi-misi tertentu (Eriyanto, 2001) dalam Akhirul dan Akbari (2018)

Dalam penerapannya ada beberapa sudut pandang dalam menganalisis wacana. Perbedaan sudut pandang ini didasari pada adanya perbedaan pandangan mengenai bahasa. Terdapat tiga pandangan mengenai bahasa dalam analisis wacana, yaitu pandangan pertama diwakili oleh kaum positivisme-empiris. Dalam pendekatan positivisme titik perhatiannya didasarkan pada benar tidaknya bahasa itu secara gramatikal. Pandangan kedua disebut konstruktivisme. Pandangan ini melihat bahwa wacana adalah suatu upaya pengungkapan maksud tersembunyi dari sang subjek yang mengemukakan suatu pernyataan. Pengungkapan itu dilakukan di antaranya dengan menempatkan diri pada posisi sang pembicara dengan penafsiran mengikuti struktur makna dari sang pembicara. Pandangan ketiga disebut sebagai pandangan kritis. Dalam pandangan kritis, wacana dipandang sebagai praktik ideologi, atau pencerminan dari ideologi tertentu. Ideologi yang berada di balik penghasil teksnya akan selalu mewarnai bentuk wacana tertentu.

Menurut Faiclough dan Wodak (Eriyanto, 2001:7), analisis wacana kritis melihat wacana pemakaian bahasa dalam tuturan dan tulisan sebagai bentuk dari praktik sosial. Menggambarkan wacana sebagai praktik sosial menyebabkan sebuah hubungan dialektis di antara peristiwa diskursif tertentu dengan situasi, institusi, dan struktur sosial yang membentuknya. Praktik produksi teks bisa jadi menampilkan efek ideologi: ia dapat memproduksi dan mereproduksi hubungan kekuasaan yang tidak imbang antara kelas sosial, laki-laki dan wanita, kelompok mayoritas dan minoritas melalui mana perbedaan itu direpresentasikan dalam posisi sosial yang ditampilkan. Melalui wacana, sebagai contoh, keadaan yang rasis, seksis, atau ketimpangan dari kehidupan sosial dipandang sebagai suatu common sense, suatu kewajaran atau alamiah, dan memang seperti itu kenyataannya.

Analisis wacana kritis melihat bahasa sebagai faktor penting, yakni bagaimana bahasa digunakan untuk melihat ketimpangan kekuasaan dalam masyarakat terjadi. Oleh karena itu, analisis wacana dipakai untuk membongkar kuasa yang ada dalam setiap proses bahasa: batasan-batasan apa yang diperkenankan menjadi wacana, perspektif yang mesti dipakai, topik yang dibicarakan. Dengan pandangan semacam ini, wacana melihat bahasa selalu terlibat dalam hubungan kekuasaan, terutama dalam pembentukan subjek, dan berbagai tindakan representasi yang terdapat dalam masyarakat.

Pendekatan Fairclough dalam menganalisa teks dianggap lengkap karena berusaha menyatukan tiga tradisi yaitu; 1) Dimensi Tekstual (Mikrostruktural), meliputi: representasi, relasi, dan identitas 2) Dimensi Praktik Produksi Teks (Mesostruktural), meliputi: produksi teks, penyebaran teks dan konsumsi teks. 3) Dimensi Praktik Sosial Budaya (Makrostruktural), meliputi: situasional, institusional dan sosial.

Kerangka teori lain yang dapat memperkya penelitian ini Teori Ekonomi Politik Media, Kajian ekonomi politik media berawal dari pengakuan bahwa media adalah sebuah industri yang memproduksi dan mendistribusikan barangbarang yang ditunjang oleh proses integrasi dan diversifikasi. Kajian yang membahas beragamnya media tidak dapat dilakukan secara sendiri-sendiri atau tertutup, melainkan harus dipahami dengan konteks 
ekonomi makro karena keterkaitan media dengan kontrol perusahaan besar atas media.

Sebagai sebuah produk, media memiliki keunikan dibandingkan dengan produk pada manufaktur lainnya, karena media memproduksi dan mereproduksi gambaran kehidupan sosial dan kesadaran kemudian mendistribusikannya kepada konsumen atau yang biasa disebut khalayak. Institusi media memiliki tanggung jawab untuk memenuhi kepentingan publik yang termasuk dalam aspek politik dari media. Media sebagai sebuah industri dituntut untuk terus mengembangkan dirinya dalam kerangka kerja bidang ekonomi, serta ada tuntutan untuk selalu mengikuti perkembangan teknologi dengan mendistribusikan konten melalui banyak platform dalam waktu yang bersamaan.

Sebagai kajian literatur yang menunjukkan nilai kebaruan maka peneliti menggunakan penelitian yang dilakukan Akhirul \& Akbari (2018) dengan judul Media dan Kekerasan: Analisis Norman Fairclough Terhadap Pemberitaan Tarung Gladiator. Tujuan penelitian ini untuk mengetahui bagaimana wacana kekerasan dikemas dalam pemberitaan tarung gladiator pada Line Today dengan menggunakan analisis wacana kritis Norman Fairclough untuk menganalisis teks, praktik produksi teks, dan praktik sosial budaya.

Hasil penelitian menunjukkan bahwa Hasil penelitian menunjukkan bahwa Line Today memilih enam berita dari media Kumparan.com, Liputan6.com, dan Okezone.com untuk merekonstruksi kekerasan dalam kasus tarung gladiator di kalangan pelajar. Bahasa yang digunakan dalam teks berita dikemas secara ringan, singkat, dan mudah dipahami oleh generasi milenial.

Perbedaan dengan yang dilakukan peneliti dengan penelitian terdahulu terletak pada unit analisis wacana dan media yang diteliti lebih banyak dan hasilnya juga berbeda. Tetapi persamaan dengan penelitian saat ini menggunakan analisis wacana kritis Norman Fairclough.

Peneltian kedua sebagai kajian literatur berjudul Analisis Wacana Kritis Norman Fairclough Pada Pernyataan Kontroversial Viktor Laiskodat (Gasa, 2019). Penelitian ini bertujuan untuk mengkaji dan mengkritisi retorika Gubernur NTT, Viktor Laiskodat. Penelitian ini merupakan penelitian kualitatif berparadigma kritis karena peneliti berusaha untuk membedah teks berupa pernyataan-pernyataan Viktor Laiskodat. Peneliti menggunakan Analisis Wacana Kritis Norman Fairclough untuk meneliti pernyataan-pernyataan tersebut dari tiga dimensi, yakni teks, praktik wacana dan praktik sosiokultural. Retorika Viktor Laiskodat bertujuan untuk mempersuasi masyarakat NTT agar mengubah kebiasaan dan cara hidup yang lama serta bersama dengan Pemerintah mengatasi berbagai persoalan, seperti kemiskinan, Pendidikan dan kesehatan.

Persamaan dengan penelitian ini pada alat bedah yang digunakan yaitu analisis wacana krisis Norman Fairclough dan media yang diteliti. Tetapi teori yang digunakan berbeda sehingga hasil penelitian juga berbeda.

Dalam penelitian ini, permasalahan yang ingin dikaji oleh peneliti adalah bagaimana wacana vaksinasi dikemas dalam pemberitaan vaksin Covid-19 pada kompas.com? Berdasarkan rumusan masalah, maka tujuan penelitian yang ingin dicapai dalam penelitian ini adalah untuk menganalisi bagaimana postmodifikasi yang dikemas dalam pemberitaan vaksin Covid-19 pada kompas.com dengan menggunakan metode analisis wacana kritis Norman Fairclough.

\section{METODOLOGI}

Penelitian ini dilakukan dengan menggunakan metode penelitian kualitatif dengan pisau bedah analisis wacana kritis 
yang dikembangkan oleh Norman Fairclough. Pendekatan kualitatif ini memusatkan perhatian pada prinsip-prinsip umum yang mendasari perwujudan sebuah makna dari gejala-gejala sosial di dalam masyarakat (Bungin, 2017). Penelitian ini disajikan dalam bentuk uraian kata-kata (deskripsi), oleh karena itu digunakanlah metode penelitian kualitatif deskriptif. Metode deskriptif sendiri memiliki pengertian yaitu penelitian yang dirancang untuk mengumpulkan, menganalisa, serta menyajikan data informasi yang sebenarbenarnya, penelitian ini dapat memberikan gambaran yang jelas mengenai objek yang diteliti untuk menarik kesimpulan dari objek penelitian.

Penelitian kualitatif merupakan penelitian yang bersifat interpretiv yakni menggunakan penafsiran dan banyak metode dalam menelaah masalah penelitian agar diperoleh pemahaman yang komprehensif mengenai persoalan yang diteliti. Sementara itu, sebagai pisau bedah adalah analisis wacana kritis (critical discourse analysis/ CDA) yang dikembangkan oleh Norman Fairclough. Fairclough membangun analisis model analisis wacana yang mempunyai kontribusi dalam analisis sosial dan budaya, sehingga analisisnya mengkombinasikan tradisi analisis tekstual dengan konteks masyarakat yang lebih luas. (Halim, 2013)

Penelitian ini menggunakan paradigma kritis yang mempunyai sejumlah asumsi mengenai bagaimana penelitian harus dijalankan, dan bagaimana teks berita seharusnya dianalisis. Paradigma kritis mempunyai pandangan tersendiri pada media, bahwa sebuah berita harus dipahami secara keseluruhan. Dalam pandangan ini, tidak hanya melihat bahasa sebagai alat untuk memahami realitas objektif belaka, tetapi perlu melihat maksud-maksud dari wacana tertentu. Paradigma kritis jauh lebih meneliti aspek sosial, sejarah, dan budaya dari wacana tersebut. Paradigma kritis diharapkan mampu membentuk kesadaran sosial agar dapat memperbaiki dan mengubah kondisi kehidupan manusia. Oleh karena itu, subjektivitas tidak dapat dihindarkan dalam penelitian ini karena realitas yang ditemukan dalam teks merupakan hasil dari penafsiran peneliti.

\section{HASIL DAN PEMBAHASAN}

Representasi Wacana yang muncul dalam pemberitaan yang dimuat oleh Kompas.com terkait tentang Pemberitaan Vaksin Covid 19 bila dikaitkan dengan teori Post komodifikasi yang menyatakan bahwa media itu tidak dilihat dari komodifikasi isi, komodifikasi khalayak, dan pekerja tetapi Postkomodifikasi diartikan sebagai kritik yang ditujukan terhadap praktik komodifikasi dan praktik wacana yang dilakukan oleh industri media, dimana Representasi wacana menurut Norman Fairclough adalah bahwa Representasi wacana ini lebih fokus kepada teks yang akan dianalisis secara mendalam. Hal ini disebabkan teks merupakan bentuk representasi sesuatu yang mengandung ideologi tertentu, sehingga teks dibongkar secara linguistis atau dengan melihat aspekaspek kebahasaan, yaitu kosakata, semantik, tata kalimat, koherensi, dan kohesivitas yang membentuk suatu pengertian.Seperti pada pemberitaan berikut ini, dimana Vaksin Covid19 yang diterbitkan di Indonesia itu ada 3 jenis sesuai dengan berita yang disampaikan kompas.com pada tanggal 29/08/2020 dengan judul berita "Vaksin Covid-19, Apakah Sudah Sesuai Virus Corona di Indonesia?" , ini menunjukan bahwa berita tersebut merepresentasikan atas wacana yang muncul terhadap audience nya sehingga terkomodifikasi bahwa vaksin covid 19 yang digunakan di Indonesia adalah yang ditampilkan dalam wacana pemberitaan tersebut.

Berbeda dengan Representasi, Relasi Wacana dalam Analisis Wacana Kritis (AWK) adalah melakukan analisis 
pada pemberitaaan Vaksin Covid 19 di Kompas .com dari sudut pandang hubungan antara wartawan, khalayak dan partisipan berita ditampilkan dan digambarkan dalam teks dimana pada pemberitaan tanggal 01/09/2020, Bila dianalisis berdasarkan relasi wacana maka diperoleh gambaran bahwa relasi artikel tersebut menjelaskan kalau Presiden sangat mendukung sekali digunakannya Vaksin Sinovac digunakan di Indonesia bahkan Jokowi berkomitmen kalau Indonesia akan mendapatkan 20 Juta - 30 Juta Vaksin pada 2020. Dengan demikian menjadi jelas bahwa kerja sama antara PT Bio Farma mewakili Indonesia dengan Sinovac asal China adalah kerjasama Indonesia dengan Cina, untuk penanggulangan covid 19.

Untuk wacana Identitas dalam penelitian ini menjelaskan bahwa Bagaimana identitas wartawan, khalayak, dan Identitas partisipan dalam berita ditampilkan dan digambarkan dalam teks, sebagai bentuk analisis pada analisis wacana kritis Norman Fairclough, sehingga semakin jelas pemetaan media tersbut dalam memberitakan pemberitaan Vaksin Covid 19, dimana Kompas.com sebagai media online nasional tentu memiliki kepentingan Merujuk pada artikel 31 Agustus 2020 jelas bahwa Kompas.com dalam pemberitaanya mencoba memberikan identitas bahwa media tersebut sangat berimbang,melihat pada teks tersebut, tidak hanya vaksi Sinovac yang berasal dari Cina yang diberikan dan GX 19 dari korea Selatan saja yang diberitakan tetapi vaksin yang dikembangkan oleh Amerika Serikat yaitu Astra Zeneca pun turut diberitakan dimana memiliki tingkat kemajuan lebih cepat dari keduanya.

Dalam AWK Norman Fairlough digunakan pula Wacana Produksi dan Konsumsi Teks (Meso) Analisis pada level meso atau discource practice memusatkan perhatian pada bidang produksi dan konsumsi teks. Teks terbentuk karena adanya suatu praktik diskursi, yang akan menentukan bagaimana teks tersebut dibentuk. Pada analisis level ini, terdapat-kekuatan terselubung" yang bersama teks (Fairclough, 2001: 41). Kekuatan terselubung tersebut menyiratkan sudut pandang tersembunyi produsen (pembuat teks) terhadap suatu topik tertentu yang sedang dibahas, yang kemudian akan mempengaruhi sudut pandang konsumen (khalayak). Merujuk pada artikel 10 September 2020 jelas bahwa Kompas.com dalam pemberitaanya mencoba memberikan alur yang jelas tentang proses penggunaan vacsin Covid 19 yang dalam proses produksi teks pemberitaanya selalu dinyatakan merek yang digunakan dan jumlah ketersediaan yang didapat Indonesia sehingga memberikan gambaran yang jelas dan terang bagi konsumen yang mengkonsumsi berita tersebut dan tidak menimbulkan interpretasi berganda, atas pemberitaan Vaksin Covid 19.

Dalam analsisi situasional yang merupakan bagian dari analisis meso, dinyatakan bahwa Kompas.com dalam pemberitaanya mencoba mengajak pembaca pada situasi yang sebenarnya sehingga mampu menghadapi realitas secara benar dan jelas. Sehingga tida adalah harapan harapan palsu yang menyebabkan pembaca justru lalai, kalau faktanya harus menunggu selama 12 samapai 18 bulan untuk menemukan Vaksi ya itu realitas yang ditampilkan oleh Kompas.com.

Begitu juga dalam institusional yang menyatakan bahwa Kompas.com dalam pemberitaanya mencoba mengajak pembaca untuk mengetahui siapa yang mejadi dominan dalam penangan Vaksin Covid ini karena banyak negara berlomba untuk meghasilkan Vaksin tersebut terutama negara negara adidaya mencoba menunjukkan super powernya untuk berebut pasar dunia ketiga. Sedang dalam analisis sosial menyatakan dengan jelas bahwa Kompas.com dalam pemberitaanya mencoba mengajak pembaca untuk melihat bagaimana fenomena sosial yang tampak 
dari pemberitaan ini adalah bagaimana presiden moncoba menunjukkan eksistensinya dimata masyarakatnya bahwa negara hadir ditengah kerisis yang terjadi.

Analisis makro atau sociocultural practice didasarkan pada asumsi bahwa konteks sosial yang ada diluar teks mempengaruhi bagaimana wacana yang muncul dalam teks. Analisis ini menentukan bagaimana teks diproduksi dan dipahami. Analisis makro menentukan teks secara tidak langsung dan dimediasi oleh praktik kewacanaan. Dalam analisis pemberitaan vaksin covid 19 di Kompas.com dinyatakan bahwa melalui data inilah berbagai skenario model, proyeksi dan juga perhitungan khususnya pemerataan kurva atau 'flattening the curve'dapat dilakukan. Sebagaimana yang mungkin diketahui, bahwa model 'flattening the curve'sempat menjadi viral dalam berbagai saluran informasi dan media lokal dan global juga media sosial, menjadikan model ini menjadi obsesi hampir semua negara di dunia dalam mencegah peningkatan kasus penyakit akibat virus COVID-19 di tingkat daerah (lokal) dan nasional. Dan untuk mendukung pemodelan ini, maka data menjadi sumber yang sangat penting, termasuk dalam proses penginformasian mengenai strategi kelangsungan hidup secara kolektif dari pemerintah kepada masyarakat dalam melawan virus corona (Woodie 2020).

Perlu dipahami, bahwa pemerintah (negara) memiliki kewajiban hukum untuk melindungi warga negaranya dalam berbagai aspek kehidupan yang menyertainya. Termasuk di dalamnya adalah aspek kesehatan masyarakat, serta hak atas jaminan sosial dan hak asasi manusia atas informasi yang transparan. Maka di satu sisi, transparansi dapat diartikan sebagai hak publik untuk mengetahui dan mengakses informasi, sementara di sisi lain, Negara harus memastikan bahwa setiap orang dapat mewujudkan hak mereka tanpa diskriminasi. Bersikap transparan tentang data dan informasi terkait COVID-19 akan membangun loyalitas dan kepercayaan masyarakat terhadap negara. Ketika tidakada informasi dan data yang disembunyikan oleh negara maka negara sedang membangun koneksi yang kuat dengan masyarakat sehingga tingkat kepercayaan masyarakat kepada pemerintah (negara) meningkat.

Transparansi data sangat erat kaitannya dengan kebebasan informasi dan kebebasan informasi adalah bagian integral dari hak fundamental kebebasan berekspresi, sebagaimana diakui oleh Resolusi 59 Majelis Umum PBB yang diadopsi tahun 1946, serta Pasal 19 Deklarasi Universal Hak Asasi Manusia (1948) yang menyatakan bahwa hak dasar kebebasan berekspresi mencakup kebebasan untuk "mencari, menerima/mendapatkan dan menyampaikan informasi dan ide melalui media apapun dan tanpa memandang batas" (Nations 1948). Lebih jauh, kebebasan informasi akan mendukung lembaga yang lebih bertanggung jawab dan transparan, serta penting bagi supremasi hukum. Artinya, transparasi menyiratkan keterbukaan pemerintah akan data-data yang valid, benar, aktual, komunikasi dan akuntabilitas negara. Terlebih dalam situasi darurat COVID-19, transparansi data menjadi elemen penting yang tidak dapat dihiraukan oleh negara.

\section{SIMPULAN}

Dalam konteks ini, wacana politik yang berkembang dalam pemberitaan Vaksin Covid 19 di Kompas.com adalah: Pertama Pemberitaan Vaksin Covid 19 bukanlah hanya pemberitaan tentang penemuan obat vaksin saja, melainkan pemberitaan tentang kehebatan negara negara maju dalam perang melawan Covid 19 akibatnya wacana politk yang 
berkembang justru adalah pertarungan politik yang terjadi antara US sebagai negara adidaya mewakili Eropa dan Cina negara adidaya mewakili Asia.. Teks berita merepresentasikan keunggulan Cina dalam mengatasi Virus Corona luar biasa sehingga Indonesia pun yang mecoba obyektif terhadap Vaksin Covid 19, menjadi tertarik tarik atau tersangkut kedalam konflik kedua kekuatan besar tersebut.

Kedua Pemberitaan Vaksin Covid 19 dianggap sebagai pertarungan identitas. Wacana politik yang berkembang merepresentasikan pertarungan identitas kedua negara adidaya dalam memenangkan pertempuran melawan Covid 19 Pemberitaan yang menonjolkanpersaingan dua blok tersebut tergambar dalam produk Vaksin yang diproduksinya dimana Cina dan Korea Selatan digunakan oleh Indonesia sedangkan Vaksin US yang mengaku sudah uji klinis namun oleh WHO dipertanyakan keampuhannya dan diminta untuk dilakukan pengujian kembali,sedangkan Rusia yangdipanang sekutunya US dengan mengaku sudah memproduksi Vaksinnya secara masal dalam perjalannya ditemuka beberapa persoalan. Di satu sisi Sinovac atau vaksn dari China yang di uji diIndonesia sempat diramaikan dengan rlawan yang sudah dua kali disuntik Vaksin masih tetap terkena positif Covid, oleh pihak pemerintah dilakukan klaifikasi, namun disisi yang lain hal tersebut dianggap keberpihakan. merujuk pada pertarungan identitas yang digunakan untuk memperjelas hubungan di antara anggota masyarakat yang dapat menciptakan sentimen identitas.

Dalam konteks berikutnya, yakni postkomodifikasi informasi dalam berita Vaksin Covid 19 di Kompas.com, dapat disimpulkan bahwa Kompas.com sebagai media siber memproduksi berita (pengetahuan) sebagai sandaran untuk memperoleh pengakuan dengan memanfaatkan berita Vaksin Covid 19 sebagai bagian dari marketing media, mendapatkan dukungan dan bentuk dari representasi ideologi media. Digitalisasi membuat Kompas.com menjadikan berita sebagai bagian dari referensi atas style dan modernitas dalam masyarakat informasi.

Bentuk postkomodifikasi informasi dalam berita Vaksin Covid 19 di Kompas.com dapat dijelaskan dalam 3 poin berikut: Pertama, Berita sebagai industri milenial. Berita dalam fungsi dasarnya sebagai informasi telah beralih menjadi industri media dan bagian dari referensi masyarakat milenial dalam hal konsumsi informasi untuk dapat dianggap mengikuti perkembangan tren yang sedang ada (up to date) dengan memanfaatkan masyarakat milenial sebagai objek sasaran. Kedua, Berita sebagai amunisi kompetisi politik. Berita tidak lagi menjadi alat rasionalistas politik bagi masyarakat untuk menentukan pilihan-pilihan politik yang rasional, berita dalam konteks ini telah beralih menjadi amunisi bagi para pelaku atau aktor politik dalam menghadapi kompetisi politik. Ketiga, Berita sebagai identitas partisan politik. Berita tidak lagi bersifat universalitas (umum/menyeluruh) karena informasinya menyangkut kepentingan kelompok tertentu, dan ditujukan pada kelompok tertentu. Berita telah menjadi bagian dalam menunjukan identitas partisan politik kepada publik.

\section{DAFTAR PUSTAKA}

Baran, S. J. (2012). Pengantar Komunikasi Massa: Melek Media \& BudayaTitle (S. Rouli Manalu (ed.)). Erlangga.

Barker, C. (2009). Cultural Studies: Teori \& Praktik (N. Nurhadi (ed.)). Wacana., Kreasi.

Burton, G. (2017). Media dan Budaya Populer. Jalasutra.

Deddy Mulyana, S. (2013). Metode Penelitian Komunikasi. PT Remaja Rosdakarya.

Eriyanto. (2001). Analisis Wacana: Pengantar Analisis Teks Media. LKis. 
Foucault, M. (n.d.). Power/Knowledge: Wacana Kuasa/Pengetahuan (Y. Santosa (ed.)). Narasi-Pustaka Promethea.

Halim, S. (2013). Poskomodifikasi Media. Jogjakarta: Jalasutra.

Halim, S. (n.d.). Postkomodifikasi Media: Analisis Media Televisi dengan Teori Kritis dan Cultural Studies. Jalasutra.

Hardiman, F. B. (1990). Kritik Ideologi: Pertautan Kepentingan dan Pengetahuan. Kanisius.

Holmes, D. (n.d.). Teori Komunikasi: Media, Teknologi dan Masyarakat (W. Utomo (ed.)). Pustaka Pelajar.

Ibrahim, I. S. \& B. A. A. (2014). Komunikasi \& Komodifikasi: Mengkaji Media dan Budaya dalam Dinamika Globalisasi. Buku Obor.

Jarvis, M. (2006). Teori-Teori Psikologi: Pendekatan Modern untuk Memahami Perilaku, Perasaan \& Pikiran Manusia. (SPA-Teamwork (ed.)). Nusa Media.

Lubis, A. Y. (1998). Sebuah Dunia yang Dilipat: Realitas Kebudayaan Menjelang Milenium Ketiga dan Matinya Postmodernisme. Mizan.

Mansur, D. G. \& F. (2017). Metode Penelitian Kualitatif. Ar Ruzz Media.

Nasrullah, R. (2014). Teori dan Riset Media Siber. Kencana.

Nasrullah, R. (2015). Media Sosial,Prespektif Komunikasi, Buda dan Sosioteknologi. Bandung: PT Remaja Rosdakarya.

Piliang, Y. A. (2015). Post-realitas: Realitas Kebudayaan dalam Era Postmetafisika. Jalasutra.

Ritzer, G. (2010). Teori Sosial Postmodernisme (M. Taufik (ed.)). Kreasi Wacana.

Ruben, B. D. dan L. P. S. (2013). Komunikasi dan Perilaku Manusia. RajaGrafindo Persada.
Sobur, A. (n.d.). Analisis Teks Media. Remaja Rosdakarya.

Titscher, S. (2009). Metode Analisis Teks \& Wacana (Gazali (ed.)). Pustaka Pelajar.

Amir, Y., Posmodernisme, P., Komunikasi, E., \& Piliang, Y. A. (2001). Posmodernisme dan Ekstasi Komunikasi. Mediator: Jurnal Komunikasi, 2(2), 165-176. https://elearning2.unisba.ac.id/index.p $\mathrm{hp} /$ mediator/article/view/716

Kompas.com. (n.d.). Kompas.com Tersertifikasi dalam Jaringan Internasional Penguji Informasi. ttps://www.tribunnews.com/kabarpalmerah/2018/11/16/kompascomtersertifikasi-dalam-jaringaninternasional-penguji-informasi

Ridwan, M. (2017). Komodifikasi dan Konfergensi sebagai Strategi Bersaing (Studi Kasus: Harian Kompas EPaper).

Subandy, Idy Ibrahim;Ali, B. (Ed.). (n.d.). Komunikasi \& Komodifikasi Mengkaji Media dan Budaya dalam Dinamika Globalisasi Part1merged.pdf.

Karman. (2012). Media Dan Konstruksi Realitas (Analisis Framing Terhadap Pemberitaan Koran Tempo Mengenai Kasus Ledakan Bom di Masjid Mapolres Cirebon). Jurnal Studi Komunikasi Dan Media, 27-45.

Kusuma, S. (2016). Posisi Media Cetak Di Tengah Perkembangan Media Online Di Indonesia. Interact, 56-71.

Nurkinan, D. (2017). Dampak Media Online Terhadap Perkembangan Media Konvensional. Jurnal Politikom Indonesiana , 28-41.

Waluyo, D. (2017). Makna Jurnalisme Dalam Era Digital Suatu Peluang Dan Transformasi. Jurnal Kementrian Komunikasi dan Informasi RI, 33-42. 